\title{
Erratum to: Histomorphological study of ovarian atresia over the reproductive cycle of Octopus vulgaris from Galician waters (NW Spain)
}

Pilar Sieiro $^{1}$ (D) Jaime Otero ${ }^{2} \cdot$ Ángel Guerra $^{2}$

Published online: 6 May 2017

(c) Springer-Verlag Berlin Heidelberg 2017

Erratum to: Zoomorphology (2016) 135:419-431

DOI 10.1007/s00435-016-0322-y

Unfortunately, in first sentence of the "Results" section of list 3.3, the word "scar" was incorrectly published in the original publication of this article. The line should read as follows:

"At this stage, the atretic oocytes begin to be easily confounded with ovarian connective tissue, remaining like a scar in the ovary".

The online version of the original article can be found under doi:10.1007/s00435-016-0322-y.

\footnotetext{
Pilar Sieiro

psieiro@cetmar.org

1 Centro Tecnológico del Mar, Fundación CETMAR, Eduardo Cabello s/n, 36208 Vigo, Spain

2 Instituto de Investigaciones Marinas (CSIC), Eduardo Cabello 6, 36208 Vigo, Spain
} 